\title{
De Motu Cerebri: The History of the Study of Brain Pulsations
}

\author{
Moshe Feinsod*
}

Faculty of Medicine, The Technion, Israel Institute of Technology, Haifa, Israel

\begin{abstract}
Pulsations of the brain were observed and noted since antiquity. Galenic concepts that the brain pulsations propel psychic pneuma to the nerves were challenged during the Renaissance and replaced by other theories. During the age of the Enlightenment, scientists began to study by observation and experiment whether these pulsations were generated by the dura mater, the respiratory movements or the beating of the heart through the arteries and the veins. The research efforts then moved to find out whether the pulsations were an innate physiological phenomenon or whether they appeared only when the skull was opened. The devices developed during the first half of the nineteenth century, enabled observing the brain while preserving the conditions of an unopened skull. They are the prototypes of nowadays instruments in clinical use.

The invention of the kymograph transformed the naked eye impressions into records that were open to objective analysis, and established the close relation between the arterial pulse and its components to the waveform of the cerebral movements. By the end of the nineteenth century, the study of the brain movements was coupled with the extensive research of the cerebral circulation, emotional conditions and the physiology of intracranial pressure; however, this endeavor was abandoned for many decades.

As continuous monitoring of intracranial pressure in the late 1970s became a routine clinical practice, the three-centuriesold research of brain pulsations was resumed with the not yet fulfilled aspiration to employ wave-form analysis of the pulsations as a means for non-invasive assessment of intracranial pressure.
\end{abstract}

Keywords: Brain, pulsations, history of medicine.

\section{INTRODUCTION}

More than a century ago, the historian of the experimental neurosciences Max Neuberger studied the history of the research on brain pulsations and caustically proclaimed "The problem was relatively simple one, requiring no complicated experimental procedures; the only obstacle was the regrettable predominance of rigid doctrines that distorted the obvious facts and altered them in favor of vague speculations. ...In the whole history of brain physiology there is no development strange as this." [1]. The argument of this paper is that if we liberate ourselves from a judgmental attitude towards our predecessors and study the development of the ideas and endeavors to understand the pulsations of the brain through phases of speculation and observation to planned experiments, we shall realize that for them the problem was not that simple - the emancipation from more than a millennium old rigid doctrines was arduous and the instrumentation needed for the research was quite sophisticated for its time. Even nowadays as we are holding in our hands the best technological achievements, there are still unresolved problems in the study and application of such a basic phenomenon.

\section{FROM ANTIQUITY TO THE AGE OF THE EN- LIGHTENMENT}

Since primeval times any parent that laid finger on an infant's fontanel could feel the rhythmic pulsations beneath

*Address correspondence to this author at the Faculty of Medicine The Technion, 6 Efron St. Bat Galim, Haifa, 31096, Israel; Tel: +97248265106; Fax: +97248265105; E-mail: Moshe.feinsod@gmail.com it. It is highly probable that the prehistoric performers of trepanations were aware of the throbbing dura once it was exposed. Being prehistoric, there is no record of it. The pulsations of the intra cranial contents could have been observed through gaping craniocerebral wounds but there is no allusion to this phenomenon in the ancient Egyptian or Mesopotamian medical texts. Aristotle (384-322 BCE) mentioned the rhythmic beatings of the fontanels without further discussion. The Roman naturalist, Pliny the Elder (23-79 $\mathrm{CE})$, recounted that the pulsations of the fontanel of the infant Persian semi-god Zoroaster were so strong that they repulsed hands laid on his head, a sign of his intense brain activity [1].

Galen [2] thought that the inspired air is essential for the elaboration of the psychic pneuma that was sent from the brain to the various parts of the body. He pondered whether the air entered, through the cribriform plate, the anterior ventricles of the brain in the course of the respiratory movements, causing it to rise and sink, or did the ventricles themselves possess the capability of performing their own breathing movements. He thought that the space between the pia and arachnoidal layers was needed for the brain's movements during its respirations. Galen observed, during vivisections, that the brain pulsates in a movement similar to the throbbing of the arteries and assigned to the brain the ability to contract and expand in movements comparable to those of the heart. The idea that the brain itself has the ability to create its own movements and the power to send the psychic pneuma in to the ventricles and the nerves was in accord with his concept of the hegemony of the brain. Galen's description of two rhythms characterizing the movements of 
the brain was, however, lost almost to oblivion. It is plausible that Galen was not the only one who observed brain movements in the ancient world, nevertheless apart from Oribasius (circa 325-400 CE) and Aëtius (circa $540 \mathrm{CE}$ ) we have no authentic evidence for others referring to their occurrence. Islamic Medicine did not contribute significant additional knowledge or ideas to the subject [1]. The Galenic concept of the pulsating brain dominated medical thinking for nearly fifteen hundred years. In the sixteenth century anatomists and surgeons did not feel bound anymore to the canonized Galenic doctrines and authority, so that Fallopio (1523-1562) and others could deny, without fear, the existence of cerebral pulsations. "Since reason dictates the complete contrary to me, even the arguments that are adduced by Galen do not carry enough weight to persuade me that the movement exist in that organ, whose all substance is opposed to movement; and that it pulsate I have never been able to establish, either by dissecting living animals or by examining large head wounds or by any other evident means, although I have applied the great amount of study and diligence to this matter" the surgeons and anatomists such as Colombo (1515-1559) or Piccolhomini (1526-1605) adhered to the Galenic concept "...not only the heart but the brain has a perpetual diastole and systole... if you study anatomy diligently and examine a great number of recent head injuries you will find out that it is true.." [3].

The capability of the brain to create its own movements in order to propel the psychic pneuma was disputed by anatomists of the seventeenth century. Willis (1621-1675) who represents a later doctrine maintained that the brain was immobile. Having the impression that the dura has contractible fibers, he regarded that membrane as an active motor organ. The firm attachment of the dura to the skull did not deter him and he postulated that there are regions and cavities of the sinuses in which the movements occur. He compared the chordae within the dural sinuses to those seen in the heart ventricles [4].

John Mayow (1641-1679) carried the idea even further [5]. According to him the pulsations of the thicker meninges that surround the brain pressed the nutritious nitro-aërial spirits out of the arterial blood into the brain. "For it is probable that the dura mater behaves like another diaphragm by the help of which the brain draws in nitro-aërial spirits and in breathes." Mayow mused whether the pulsations of the heart or even respiration were generated by the meninges of the cerebellum (the origin of the nerves that innervated the heart). According to his observation, an increase of "motive and sensory function" will result in stronger constriction of the meninges; during sleep the dura "ceases to motion" over the cerebrum but "natural" motions continue over the cerebellum. Mayow's ideas may seem odd but the changes in the pulsations of the brain during mental and motor activities as well as during sleep will be a matter of interest and were reinvestigated by the second half of the nineteenth century.

The anatomist Antonio Pacchioni (1665-1726) known for his researches on the meninges of the brain [6] followed together with his colleague Giorgio Baglivi (1668-1707) the idea that the dura governed the functions of the body since all the nerve sheaths were in continuity with the dura. Pacchioni postulated that the dura is made of three muscles and four tendons thus resembling the heart. According to this concept the heart was responsible for the circulation of the blood while the dura was pumping the nervous fluid and was commanding the pulsations of the heart, hence their synchronous beatings. As evidence, Baglivi demonstrated that stimulation of the dura caused increased spurting of blood from an injured artery; the abundant sensory innervations of the dura and the vagal response to its stimulation were yet unknown. On the other hand there were studies that compared the structure of the dura to that of the musculature of the bladder. The title "cor cerebri" (brain's heart) for the dura was thus coined and shared by others [1,7]. It seems that these speculations were regarded so implausible up to the denial of any movement of the brain in the normal state [8]. Physiologists like Alexis Littre had to re-establish the very existence of the pulsations of the brain [9].

\section{THE EVE OF THE EXPERIMENTAL APPROACH}

In $1703 \mathrm{H}$. Ridley reported to the Royal Society in London on an experiment he conducted to elucidate Baglivi's theory. He trephined the skull of a living dog, enlarged the bony opening and watched the movements of the dura; he then excised all the laid open dura and ascertained that the brain continued to pulsate in the same rhythm. Ridley and the people around him laid their fingers over the exposed brain and felt its movements. Through a cortical incision he inserted a finger into the brain and felt the brain pulsating around it. He further argued that it were the pulsating arteries that moved the brain [10]. The influence of the PacchioniBaglivi concept was still so strong that the Dutch physician Schlichting [11] and his contemporaries [12-15] found it necessary to conduct, nearly half a century later, a similar experiment in various animals to repudiate any contractile property of the dura.

Ridley's rather simple experiment disproved the two centuries old concept of the dura's involvement in nervous activity and established its role as the strong fibrous membrane mechanically protecting the brain.

The French Royal academies of Sciences and Surgery, that established France as a center of physiological research during the eighteenth century, had special interest in brain injuries and related subjects [16]. A number of experimental studies on the pulsations of the brain were conducted and published under their auspices.

In $1741 \mathrm{Du}$ Verney [17] published his study stating that the pulsations of the dura depended on both the heart beats and the respiration rhythms but it was not considered to be sufficiently definitive and served only as an initiator of a number of experimental studies directed to establish the true relationship between the three rhythms. Thus Schlichting [11] reported to the French academy that the whole brain (cerebrum and cerebellum) rose during expiration and sank in inspiration. He observed that all the stimuli that affected breathing also influenced the pulsations of the brain too. $\mathrm{He}$ could not explain whether the movements were caused by the influx of blood or air into the brain. Like Ridley [10] he inserted a finger into the brain substance to feel its movements but old concepts of contractility were so deeply embedded that he, together with some colleagues, were convinced that they felt "brain fibers" contracting and relaxing with respiration, especially during the labored breathing during the convulsions that seized the injured animal. In the 
decade of 1750-1760, the great physiologist Haller [12] inspired some major works on the pulsations of the brain that were presented to France's learned societies. His teachings and his aphorism - "The brain is not raised and does not drop; it becomes alternatively larger and smaller" referring to the blood volume in the brain - may be the seeds of the research on the relationship between heart-lung physiology and the cerebral circulation.

De Lamure from Montpellier presented in 1749 the results of his researches to his faculty. They were published only in 1753 under the auspices of the Royal Academy of Sciences [13]. In a series of animal experiments and observations made on infants with open fontanelles he concluded that the brain pulsations were in the rhythm of the heart and were superimposed on the changes of the brain volume during the respiratory movements. According to De Lamure the major blood vessels were compressed, in the chest, during expiration, and blood was forced into the cerebral arteries and venous drainage was obstructed. With inspiration all the blood vessels relaxed and the blood that caused the cerebral swelling was emptied into the brain.

Haller's student Waltsdorf carried experiments on various animals and came to similar conclusions. Like Haller he insisted that the cerebral pulsations existed only in head injuries that exposed the brain, in the fontanelles or in skull defects. Furthermore; enthused by Haller's concept of "irritation", he hypothesized the existence of fibers within the brain that contracted and expanded in reaction to respiratory changes as in vomiting, sneezing, barking etc. [15]. It was difficult for scholars who saw movement in so many organs to regard the brain as an inert mass transmitting the activity of other organs and to abandon the idea of the "contracting brain". The study of the pulsations of the brain was thus drawn back by half a century.

Lorry found it necessary to dismiss [14], once again, the Pacchioni-Baglivi concept and to refute the ideas of the contractility of the brain or its coverings. He affirmed so by conducting repeated experiments on a variety of animals and maintained, as Lamure [13] couple of years earlier, that the cerebrum pulsated in a rhythm synchronous with that of the heart, riding on the respiratory movements. Additionally, he argued, that the arteries of the brain reflected the heart pulsations differently from other organs, because of the short distance between the heart and the brain. Lorry suggested that the rabbit should be used as the experimental animal being "quieter" during the experiments. Other investigators like Bichat [18] and Richerand [19] claimed that the pulsations of the major arteries at the base of the skull were the only source of the movements of the brain. The contribution of the arterial pulsations was proven also by the ligation of the carotid and vertebral arteries [13]. Richerand downgraded the contribution of respiration to the movements of the brain. It is only plausible that the struggling, howls and laborious breathing of the animals that intermingled with periods of "relaxation" were the sources of differences between the observers. The same may be said to those who were observing soldiers or civilians whose brain was laid bare by trauma. It was Dorigny [20] that concluded in his experiments that the cerebral pulsations originated from the respiratory movements as well as from the arterial pulse. He stressed, however, that they were evoked only by sensory stimuli. The opinion shared by the majority of the investigators was that the movements of the brain were not a physiological phenomenon and existed only in the not yet calcified skull or in the exposed brain. This question is to remain unsolved for several decades.

\section{THE RECORDING REVOLUTION}

In 1811 Francesco Ravina [21] presented to the Turin Academy of Sciences his study entitled "Specimen de motu cerebri". In this innovating study Ravina introduced a new dimension; for the first time, the use of instruments, specially designed to enable not only the demonstration of the pulsations of the brain but also their measurements. The use of these devices signifies the crucial shift in the history of physiology from qualitative to measurable observation.

The instrument was rather simple. A tube was fitted accurately into a trepan hole (Fig. 1A). An inner, free moving, cork cylinder (Fig. 2B) could float over water that filled the hole made in the skull. The cork was stabilized by two rods (Fig. 2B) one of them carrying a ruled paper (Fig. 2D). An attached glass tube filled with water served as a manometer. Any movement of the brain could be seen and most importantly, for the first time - quantified. In the present days neurosurgeons and neurointensivists may regard it as a very early prototype of the "Richmond Screw", the forefather of the modern intracranial pressure monitoring devices. Ravina's experiments were appreciated as groundbreaking and were cited as such repeatedly for more than a century and a half.

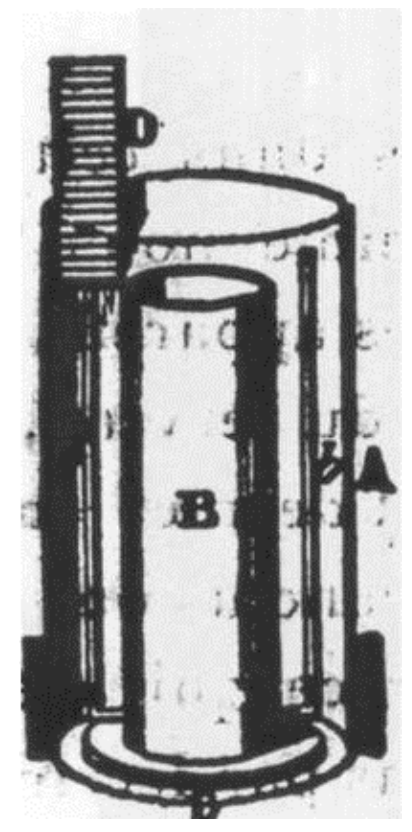

Fig. (1). Ravina's [21] device for measuring the pulsations of the brain as reconstructed by Abadie [3].

The opening of the tube was sealed by a waterproof taffeta thus imitating, to Ravina's satisfaction, the condition of an intact skull. He saw that during calm or deep inspiration the brain sank by one or three lines respectively and rose during expiration. Ravina claimed that the arteries of the dura contributed their part to the observed pulsations. Along this line The Dutch ophthalmologist Donders fit a lens into 
the trepan hole to closely observe the movements of the dural and pial vessels [22,23].

Nearly thirty years later, a more elaborate and perfected instrument was presented in a Paris doctorate thesis by M. R. Bourgougnon (Fig. 2) [24].

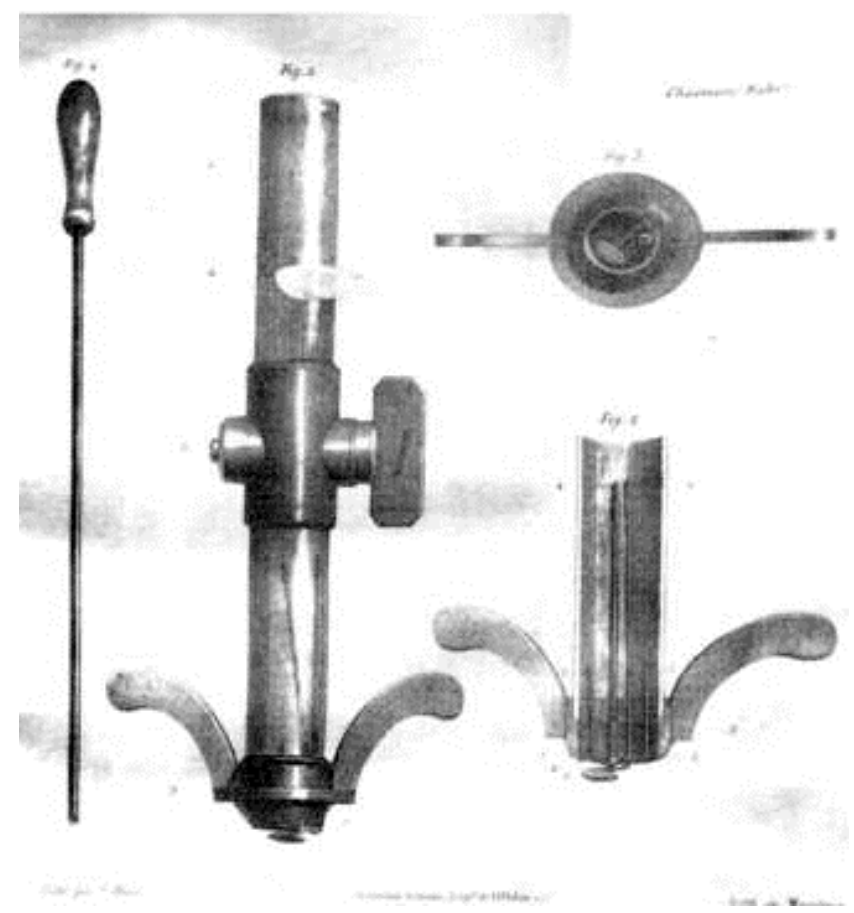

Fig. (2). Bourgougnon's instrument for measuring the pulsations of the brain. Note the possibility of screwing the cylinder into the trepan hole, and the accessories for separation of the dura. The stopcock enabled the opening (or sealing) of the cylinder's cavity to the atmosphere.

The physiologist Flourens found it necessary to restate, aided by this device, that the cerebral pulsations were the product of both the pulse and respiration [25]. Bourgougnon concluded that in the normal state there are practically no movements of the brain. He brought forward the idea, already expressed by Megendie [26], that the cerebrospinal fluid may buffer the cerebral pulsation.

The introduction of instruments to physiology and clinical studies (the stethoscope) was not met by unanimous approval. Some have regarded it as a breach of privacy and the philosopher S. Kierkegaard lamented, without realizing his prophecy, "What a sensation stethoscopy caused! Soon we will have reached the point where every barber uses it; when he is shaving you, he will ask: "Would you care to be stethoscoped, sir?" Then someone else will invent an instrument for listening to the pulses of the brain. That will make a tremendous stir, until in fifty years' time every barber can do it. Then, when one has had a haircut and shave and been stethoscoped (for by now it will be quite common), the barber will ask, "Perhaps, sir, would you like me to listen to your brain pulses?" [27].

The invention of the kymograph, around 1850, revolutionized all fields of physiology. Every bodily movement could now be amplified, thus enabling the study of the finest and fastest events and most important - recorded and opened to objective measurements and analysis by more than one person. The generations old evolution from raw observation and unfounded speculations to experimentation and instrumentation culminated in the stylus that left its marks on the sooth-blackened paper attached to the revolving drum. The kymograph, nearly unchanged, reigned in the physiological laboratories for more than a century, replaced only then by the modern transducers and electronic monitors. The first attempts to employ the instrument to the study of the cerebral pulsations were technically imperfect [28]. In the early 1860 's the French physiologist E.J. Marey upgraded the instrument by inventing devices that enabled the recording of physiological processes without interfering. With the use of several levers and styluses, he could record simultaneously several movements. Marey and his pupils, working in an institute devoted for these researches, studied every movement, from the flight of birds, the trotting of a horse, to the movements of limbs, organs and bodily fluids [29,30]. The researches carried in Marey's institute attracted many investigators of various disciplines that visited the institute and later copied or modified the instruments according to their needs. The introduction of anesthesia and mechanical ventilation to animal experiments enabled controlled conditions and reliable results [31].

Marey's pupil Salathé [32] developed a system made of an air filled tambour affixed to the fontanel or to a skull defect. Attached to the tambour was a lever fixed to the stylus of a kymograph. Balloons or air-filled cuffs were fitted around the chest or over arteries. Salathé could thus obtain simultaneous recordings of the cerebral pulsations, the pulse and respiratory movements. Unfortunately most of the recordings in his book are of irreproducible quality (Fig. 3), however, depicts the brain movements, and changes in intracranial pressure and the pulse concomitant with calm respiration or grunting of a baby (Fig. 3).

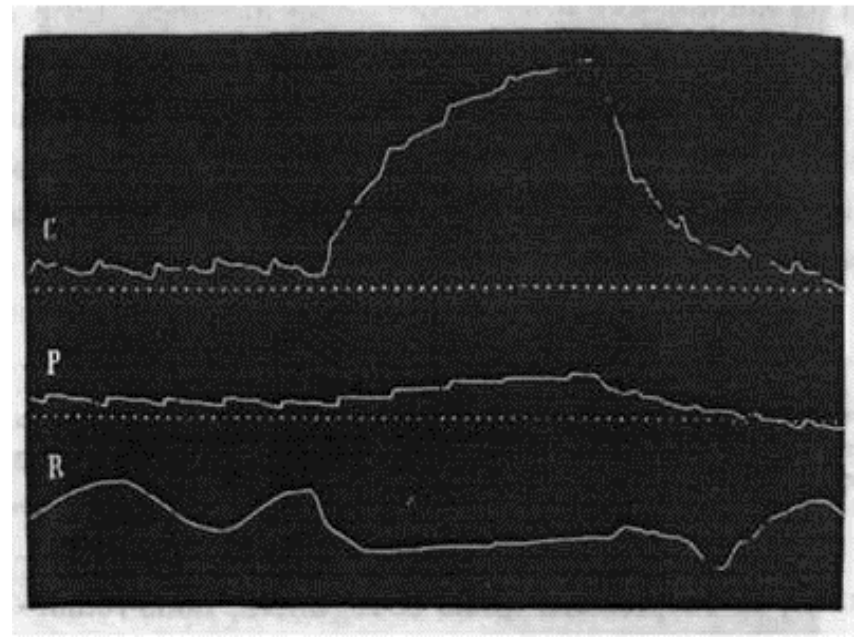

Fig. (3). Simultaneous recordings from over the fontanel (Trace C), the radial artery (Trace P) and the chest of a young baby, whose sleep is disrupted by a grunt. Note that a rise in the intracranial pressure was recorded during the breath holding.

Salathé studied a variety of physiological and pathological conditions in humans and experimental animals by recording not only from over the head but from the spinal canal too. By studying cadavers and adding an experimental 
physical model (Fig. 4) Salathé arrived to the conclusion that brain pulsations do always exist whether the skull is opened or closed. He showed that lowering the head caused an increase in the intracranial pressure and of the amplitude of the brain pulsations thus confirming the assumptions of his predecessors that the amplitude of the pulsations was a function of the amount of blood within the brain.

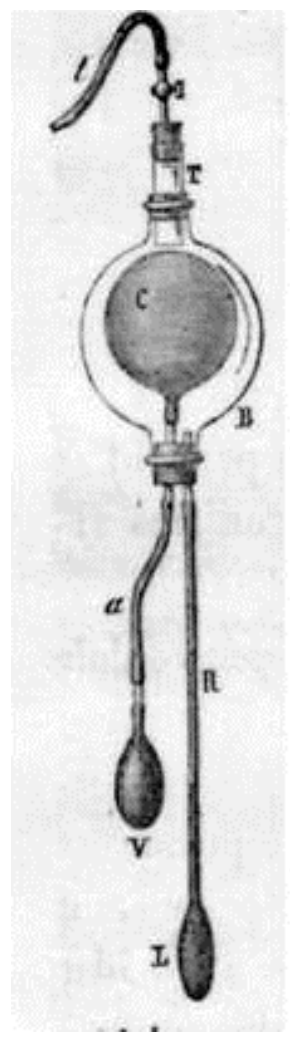

Fig. (4). Salathé's model made of concentric balloons. B represents the skull. $\mathrm{R}$ is the cerebrospinal fluid in the skull and the spinal canal. $\mathrm{V}$ and $a$ represent the heart and an artery. $\mathrm{C}$ is the brain and $t$ is the exit to the kymograph.

Similar research was conducted by François-Franck [33] the successor of Marey in running the famous institute, and Piegu [34] who demonstrated that every change in the heart beats or respiration affected the cerebral pulsations. François-Franck emphasized the importance of the venous return from the brain in determining the cerebral volume during jugular compression, raising the intra-thoracic pressure or changing the position of the head. He observed that lowering the blood flow to a limb (by exsanguinations) resulted in a marked decrease in the pulse amplitude of its main artery. Under the same conditions the amplitude of the cerebral pulsations was clearly less affected. The contemporary reader may imagine that François-Franck was on the verge of discovering the phenomenon of auto- regulation of the cerebral blood flow.

Leon Fredericq was probably the first to record simultaneously the heart and cerebral pulsations on a high speed moving kymograph drum. By this technique he could demonstrate in dogs and men that, despite difference in shape and amplitude, every component of the carotid or radial arteries pulse wave were reflected in the recording of the cerebral pulsation (Fig. 5) [35,36]. Fredericq enabled pulse wave analysis - a method to be employed in the study of intracranial pressure waves a century later.

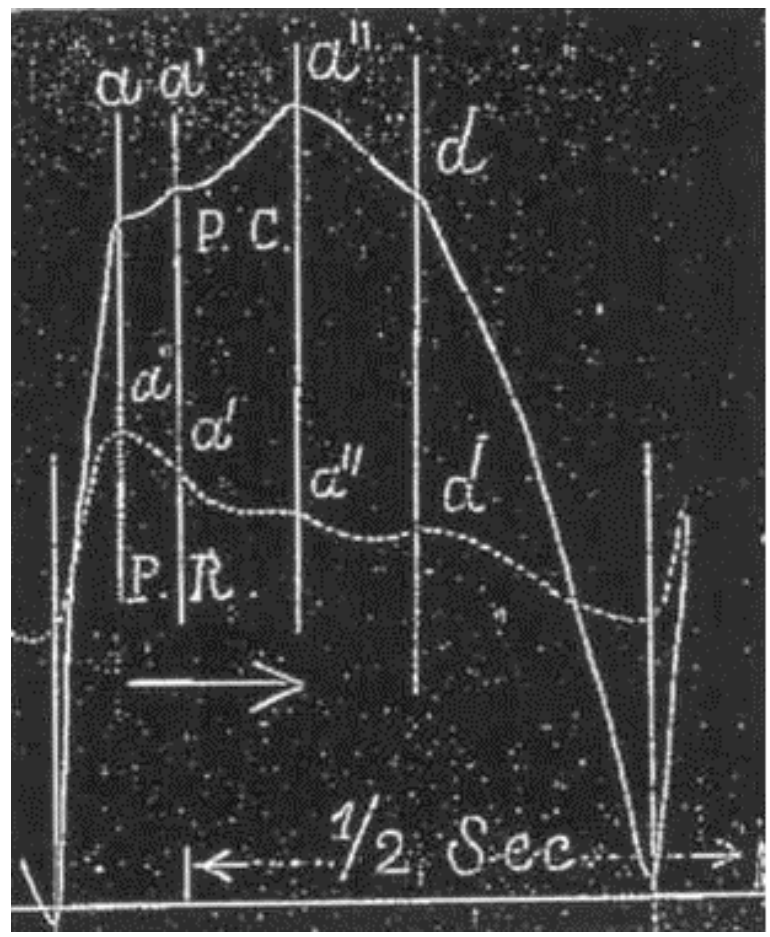

Fig. (5). Simultaneous recording of the radial pulse wave (P.R.) and the cerebral pulsation (P.C.). Note that the every component of the arterial pulse is represented in the cerebral pulse wave.

The German physiologist Leyden studied the cerebral pulsations in the context of the developing interest in the physiology of intracranial pressure [37]. His work, followed by many other German physiologists, may mark the eve of the growing interest in the relationship between the systemic blood pressure, the cerebral blood flow and the volume and pressure of the brain. The introduction of anesthesia and aseptic disciplines made intracranial surgery a forthcoming reality; and intracranial pressure was transformed from a pure theoretical issue into an applied problem of evergrowing importance. The cerebral pulsations were not regarded any more as a distinct subject but as a parameter representing cerebral blood volume, flow or intracranial pressure. This topic was studied in physiological laboratories all over Europe; it was extensively reviewed by Nobel laureate Theodore Kocher [38] and was reported also in the USA [39]. In contrast to the short length studies conducted on wake animals in the first half of that century, the introduction of anesthesia and mechanical respiration enabled prolonged experiments of several hours duration. The concept of continuous monitoring of brain pulsations in the context of intracranial pressure was thus introduced, yet it remained, for many decades, limited to the experimental laboratory.

The perception that the brain pulsations indicate the cerebral blood volume stimulated many investigators to study whether sleep and waking states are induced by or associated with "cerebral anemia" or "cerebral hyperemia" [40]. Reviving, in fact, the old Galenic observation that compression of the neck main arteries plunged the person into sleep or stupor (hence the name carotid). Inspired by Marrey and François-Franck, the Italian researchers Gia- 
comini and Mosso [41-43] used the Marrey tambour and studied extensively the cerebral pulsations in human subjects with large skull defects, most of them caused by syphilitic osteomyelitis. In some of these studies they described changes in the cerebral pulsations during emotions evoked by various stimuli fear, anger or religious experience induced by hearing the church bells, or while performing mental tasks such as simple arithmetic problems (Fig. 6).

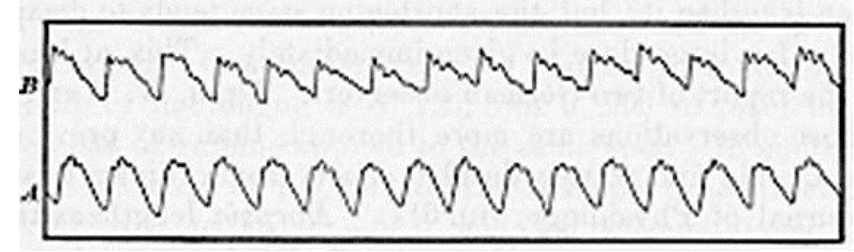

Fig. (6). Recordings made by Mosso of the cerebral pulsations during mental "repose" trace A, and during mental activity trace B.

The changes in the cerebral pulsations were regarded by Mosso as an evidence for increased blood flow to the brain during its increased activity. Mosso was not yet aware of the difference between cerebral-blood-volume and cerebral blood flow and his recordings were accepted as convincing. Researchers and clinicians alike repeated his experiments. Sir William McEwan, one of the pioneers of neurosurgery assigned Dr. Fleming, a staff member, to study the phenomenon in some of his ward patients [44] In addition to testing the effect of sleep, exercise and multiplying small numbers, Fleming recorded the "drawing of blood from the brain" after a meal or a pint of beer.

It appears that the atmosphere was prepared for these ideas, decades earlier the popular "Chambers' Edinburgh Journal" published an article about the "Influence of mental activation on health". The journal cited Sir Astley Cooper recounting two patients with skull defects through which he could see the regular and slow pulsations of the brain. "When agitated even during conversation, more blood rushed to the brain and an increased brain activity was seen" [45]. The surgeon George James Guthrie observed during the Napoleonic Wars increased pulsations of brain tissue when his head injured soldiers became agitated [46].

Mosso continued his work on vasomotor responses to various emotions but instead of using the cerebral pulsations as an indicator he elected to measure the blood volume of a limb or the flushing of the face. At the turn of the nineteenth century the interest in cerebral blood flow and intracranial pressure rose steadily while the significance of cerebral pulsations as a specific research topic seemed to fade out.

\section{EPILOG ?}

Neurosurgery, the young discipline, was not ready in the first half of the twentieth century to make clinical use of the knowledge acquired in the study of cerebral pulsations or to apply the instrumentation for continuous monitoring of the intracranial pressure. In 1922 Becher repeated the experiments of Fredericq, François-Franck and Mosso using photography of galvanometric recordings [47] but his research was not followed. Guillaume and Janny [48] published in 1951 their pioneering study of continuous manometric recording of the intracranial pressure as a clinical tool. Nine years later Lundberg published the first of his classical stud- ies on intracranial pressure dynamics in the neurosurgical setup, based on continuous recordings of the intraventricular pressure [49,50]. It was only in the late 1970s that the monitors and pressure transducers that became standard equipment in the intensive coronary care units made their way into the neurosurgical intensive care units. Guillaume, Janny, Lundberg and their colleagues recorded the intracranial pressure measurements like their nineteenth century predecessors on a long time base and were able to observe only slow changes in the intracranial pressure. The newly introduced cardiology monitors were set at a short time base to enable the study of the ECG. When used in the neurosurgical units, this setup enabled the analysis of each of the cerebral pulsations and "rediscovery" of the century old Fredericq's observation that each of the cardiac pulse wave components is represented in the cerebral pulse wave. The study of the cerebral pulsations not only changed its name to cerebrospinal pulse wave analysis [51], but, by employing the most modern technologies, it is now aiming at fascinating goals such as the assessment of the biomechanical state of intracranial tissues for the prediction of changes in the consistency and compliance of the brain and noninvasive measurement of intracranial pressure [52-54]. These fields are still budding and at present cannot be assessed with a historical perspective.

When Neuburger [1] wrote in 1897 his review of the history of the movements of the brain it may have seemed to him that the developed technology of his time solved all the problems. He thus permitted himself (see Introduction) to adopt a ridiculing judgmental attitude toward previous researchers. The study of the cerebral pulsations initiated by Galen was renewed over generations in different forms and for various aims. As it is still far from being concluded it has to remind us that we, like our predecessors, are just trying to do our best in the framework of the governing concepts and available means.

\section{ACKNOWLEDGEMENTS}

The author is indebted to the kind help of Mrs. M. Mandelbaum and Mrs. E. Shaner of the library of New York Academy of Medicine and to Mrs. M. Cohn Head Librarian of the Faculty of Medicine, The Technion, Haifa Israel.

\section{REFERENCES}

[1] Neuburger M. Experiments on the dura mater and on brain movement. In: The historical development of experimental brain and spinal cord physiology before Flourens 1897. In: Clarke E, Ed. Baltimore: Johns Hopkins University Press 1993; pp. 71-92.

[2] Rocca J. The elaboration of psychic pneuma. In: Galen on the brain. Leiden, Boston: Brill 2003: pp. 303-10.

[3] Abadie A. Recherches historiques et critiques sur les movements du cerveau. Paris: Thése de la Faculté de Médicine de Paris 1878.

[4] Willis T. The anatomy of the brain and nerves 1664; William Feindel, editor, Tercentenary ed., 1664-1964 Montreal: McGill University Press 1965.

[5] Mayow J. The animal spirits by which muscular contraction is produced consists of nitro-aerial particles. Incidetaly, as a motion of the brain. Medico-physical works; being a translation of tractatus quinque medico-physici. 1681. Edinburgh: The Alembic Club 1907; pp. 260-9.

[6] Brunori A, Vagnozzi R, Giuffre R. Antonio Pacchioni (16651726); early studies on the dura mater. J Neurosurg 1993; 78: 51518.

[7] Wit HCD de. Les fibres. In: Histoire du développement de la biologie. Lausanne: Press Polytechniques et Universitaires Romandes 1993; p. 120. 
[8] Charleton W. Natural history of nutrition, life and voluntary motion. London: H. Harrington 1659.

[9] Littré A. Observation sur la grande pituitaire d'un home. Paris: Mémoires de l'Academie Royale des Sciences à Paris 1707; pp. $125-40$.

[10] Ridley H. An experiment to discover the cause of the motion of the dura mater. Philos Trans (Abridged English Translation) 1700; 5: 201-3.

[11] Schlichting M. De motu cerebri. Mémoires de Mathématique et de Physique 1750; 1: 113-35.

[12] Haller A von. Expériences sur le movement du cerveau qui depend sur du reflux du sang. Mémoires sur la nature sensible et irritable des parties du corps animal. Lausanne: F. Grasset 1762: Vol. 1: pp. $158-92$.

[13] Lamure FB de B de. Mèmoire sur la cause des mouvements du cerveau, qui paroissent dans l'homme et dans les animaux trepans. Histoire de l'Académie Royale des Sciences [1749] 1753; 541-68.

[14] Lorry AC. Sur les movements du cerveau et de la dure-mère. Premiere mémoire, sur le movement de parties continues dans le crane, onsidérées leur état naturel. Mémoires de Mathématique et de Physique 1760; 3: 277-313.

[15] Walstorf JD. Experimenta circa motum cerebri. Gottingen: JCL Schultz 1753

[16] Bakay L. The French Royal Academy and its prizes. Neurosurgeons of the Past. Springfield Ill: Charles C Thomas 1987.

[17] Du Verney JG. Du cerveau et de ses dependences. Oevres anatomiques. Paris: C-A Jombert 1741.

[18] Bichat, X. Recherches physiologiques sur la vie et sur la mort. Paris: Brosson, Gabon et Cie 1799.

[19] Richerand A. Mémoire sur les mouvements du cerveau. Mémoires de la Société Médicale d'Émulation de Paris 1799; 3: 197-212.

[20] Dorigny. Expériences et observations sur les mouvemens du cerveau. Journal de medicine et chirurgie 1809; 17: 443-446.

[21] Ravina F. Specimen de motu cerebri. Mémoires de l'Académie des Sciences de Turin 1811; 20: 61-93.

[22] Donders FC. Beobachtungen uber die krenkheiten dem cerebrale Blut Kreislaufen. Leipzig 1847.

[23] Donders FC. De bevegingen der hersenen en de veranderingen der vaatvulling onuitzetberen schedel regstreeks van der "Pia Mater" ook bij gesloten onderzocht. Nederlandsche Lancet 1850; 5: 52153.

[24] Bourgougnon MR. Recherches sur les movements du cerveau. Paris, Thése de la Faculté de Médicine de Paris 1839.

[25] Flourens P. Nouvelles experiences sur les deux mouvements du cerveau, le respiratoire et l'artériel. Gazette médicale de Paris 1848; 3: 571 .

[26] Magendie F. Recherches physiologiques et cliniques sur le liquid céphalorachidien ou cerebrospinal. Paris: Meigs 1842.

[27] Kierkegaard S. Journals and papers 1846. A selection translated by A. Hannay. London: Penguin Books 1996.

[28] Bruns V. Praktische Chirurgie. Tubingen; Laupp 1854.

[39] Marey EJ. Animal mechanism: A treaties on terresial and aerial locomotion. New York: Appleton 1873.

[30] Marey EJ. The graphic method in experimental sciences and on its special application in medicine. Br Med J 1876; 1: 1-3; 65-6.

[31] Orlans FB: The beginnings of institutionalized animal experimentation: nineteenth century highlights, In the name of science: Responsible animal experimentation. Oxford New York, Oxford University Press 1993. pp. 3-19.

[32] Salathé A. Sur les mouvements du cerveau et le mechanism de la circulation de centres nerveux. Paris: Masson 1877.
[33] François-Franck C. Recherches critiques et expérimentales d'expansion et de resserrements du cerveau dans les rapports avec la circulation et la respiration. Journal de l'anatomie et physiologie 1877; 13: 267-307

[34] Piegu. Note sur certains mouvements des members sous la dependence du coeur et de la respiration, sur leur assimilation aux mouvemens du cerveau et la liquid céphalorachidien. Journal de l'anatomie et physiologie 1872; 8: 160-80.

[35] Fredericq L. Recherches sur la respiration ela circulation; la courbe plethysmographique du cerveau du chien. Archives de Biologie (Gand) 1885; 6: 65-102.

[36] Fredericq L. Note sur les movements du cerveau de l'homme. Archives de Biologie (Gand) 1885; 6: 103-10.

[37] Leyden E. Ueber Hirndruck und Hirnbewegungen. Virchow Archives Pathologie und Anatomie 1866; 37: 519-59.

[38] Kocher T. Hirnerschschutterung, Hirndruck und Chirurgische Eingriffe bei Hirnkrankheiten. Wien: Alfred Holder 1901.

[39] Chaillé SE. The physiology of the cerebral circulation, cerebrospinal fluid and cerebral movements. New Orleans J Med 1868; 21: 700-18.

[40] Langlet. Étude critique sur quelque points de la physiologie du sommeil. Paris: Thése de la Faculté de Médicine de Paris 1872.

[41] Giacomini C, Mosso A. Ricerche intorno di movimenti del cervello nell'uommo. Spalanzani 1876; 14: 537-9.

[42] Mosso A. Introdizione ad una serie di esprienze sui movimenti del cervello nell'uomo. Archivo per le societa medicale de Torino. 1876; $1: 206-44$

[43] Mosso A. Kreislauf des Blutes in Menschlichen Gehirn. Leipzig: Verlag von Vet 1891.

[44] Fleming WJ. The motions of the brain with illustrative graphic tracings. Glasgow Med J 1877; 9: 366-82.

[45] Chambers W, Chambers R. Influence of mental activation upon health. Chambers Edinburgh Journal 1835; 4: 234-35.

[46] Guthrie GJ. On injuries of the head affecting the brain. London: Churchill 1842.

[47] Becher E. Uebr Photographisch rgistrierte Gehirnbewegungen. Mitteilungen aus den Grenzgebiten der Medizin und Chirurgie 1922; 35: 329-42.

[48] Guillaume J, Janny P. Manométrie intracranienne continue: intérêt de la method et premiers résultats. Revue Neurologique 1951; 84 131-42.

[49] Lundberg N. Continuous recording and control of ventricular fluid pressure in neurosurgical practice. Acta psychiatria Scandinavia Suppl. 1960; 36: 1-193.

[50] Riesberg J, Lundberg N, Ingvar DH. Regional cerebral blood volume during acute transient rises of the intracranial pressure (plateau waves). J Neurosurg 1969; 31: 201-3.

[51] TakizawaH, Gabra-Sanders T, Miller JD. Changes in the cerebrospinalfluid pulse wave spectrum associated with raised intracranial pressure. Neurosurgery 1987; 20: 355-61.

[52] Chu D, Levin DN, Alperin N. Assessmrnt of the biomechanical state of intracranial tissues by dynamic MRI of cerebrospinal fluid pulsations:a phantom study. Magnetic Resonance Imaging 1998; 16: $1043-8$.

[53] Uneo T, Ballard RE, Shuer LM, et al. Noninvasive measurement of pulsatile intracranial pressure using ultrasound. Acta Neurochirurgica Suppl 1998; 104: 810-9.

[54] Wagshul ME, Chen JJ, Egnor MR, et al. Amplitude and phase of cerebrospinal fluid pulsations: experimental studies and review of the literature. J Neurosurg 2006; 104: 810-9. 